\title{
REPORT ON THE FIRST EASTERN EUROPEAN CONFERENCE ON “CRYPTOCURRENCY” (5 March 2018, Bialystok, Poland)
}

The future belongs to those
who prepare for it today. Malcolm X
On 5 March 2018, in the Hall of the Faculty of Law at the University of Białystok, the First Eastern European Conference on Cryptocurrency was held, which was organized by the Student Financial Law Club in cooperation with the Student History of Law Group and the Academic Group of Commercial Law. The conference took place under the auspices of $\mathrm{PwC}$ (a network of companies offering accounting, auditing and advisory services) and Euronet Norbert Saniewski sp. j., which made it possible to organize a machine for extracting cryptocurrencies during the conference. The conference under the auspices of the Governor of Podlasie, the President of the City of Białystok and the Rector of the University of Białystok, was preceded by several months of preparations to present the subject matter so current and still undiscovered to all interested people.

The conference was opened at 8 o'clock by prof. Maciej Perkowski, associate Dean of the Faculty of Law. The professor welcomed incoming guests and listeners and emphasized to the need to learn about the phenomenon of cryptocurrencies. Then, prof. Eugeniusz Ruśkowski, the Head of the Department of Public Finance and Financial Law, had his speech. The supervisor of the Student Financial Law Club briefly presented the process of preparations that accompanied the organization of the event and thanked the present professors without whom the conference would not have been so successful.

Then, an expert panel led by dr. Ewa Lotko and dr. Urszula Zawadzka-Pąk from the Department of Public Finance and Financial Law began. Opening lecture "The dark side of cryptocurrencies and its prophylaxis" was given by prof. Wojciech Filipkowski, representing the Department of Criminal Law and Criminology at the Faculty of Law. In his speech, prof. Filipkowski referred to potential threats related to the cryptocurrency trading, he also presented possible directions of research on cryptocurrencies showing their interdisciplinary character.

The next speech during the expert panel was a lecture by prof. Sławomir Presnarowicz from the Department 
of Public Finance and Financial Law at the Faculty of Law on "Taxation of cryptocurrencies." The idea of the presentation was to present this issue on the basis of examples from practice - judgments of Polish administrative courts regarding the problem of taxation of income obtained from trading or extracting bitcoins.

Next, prof. Aleksander Maksimczuk, representing the Department of Political Economy at the Faculty of Economics and Management, gave a lecture entitled "Cryptocurrencies: succession of monetary systems development". In his speech, prof. Maksimczuk focused primarily on the genesis of money and changes in its form over the centuries.

Another lecture at the Conference was a speech delivered by prof. Lilia Abramczyk from Yanka Kupala State University in Grodno (Belarus) entitled "Вопросы налоговой юрисдикции государства и криптовалюта" (“The issue of tax jurisdiction of the state and cryptocurrencies"), which mainly concerned the signing by President of Belarus Alexander Lukashenka on 21 December 2017 the Decree No. 8 on tax concessions for science and technology parks working on the development of blockchain technology.

Next speaker - dr. Aleksander Prokopiuk, Rector of the Higher School of Economics in Bialystok - presented his lecture entitled "Consequences of the existence of cryptocurrencies - selected aspects", in which he referred to the benefits of operating cryptocurrency in the market, but also related risks.

The last speech of the expert panel was given by the Euronet representative, Mr. Sławomir Andrejczuk on "Practical aspects of the functioning of cryptocurrencies." The lecture was conducted in the form of questions asked by the participants of the event - they most often concerned the blockchain mechanism and technical issues related to the equipment used to extract various cryptocurrencies.

Among the participants of the Conference were also invited guests: prof. Stiepan Fiodorowicz Sokól, the Founder and Rector of the Belarusian Institute of Law and Business, formerly the President of the Union of Lawyers in Belarus and the Dean of the Faculty of State Law of Yanka Kupala University of Grodno, and doc. Jurij Jurijewicz Gniezdowski - Director of the Belarusian Institute of Law and Business in Grodno.
After the lunch break the second part of the Conference began, led by Magdalena Olchanowska and Marta Maksimczuk - representatives of the Student Financial Law Club. The first speech in this part was given by Cezary Pachnik, M.A., a PhD student at the Department of Public International Law, entitled "Cryptocurrencies recognized as electronic money in the EU? Status quo and consequences". In addition to issues related to the definition of electronic money, he presented what the consequences in terms of freedom of movement for virtual currencies could be to be recognized by the EU legislation as money or payment in the full meaning. Subsequent speakers represented the Institute of Commercial Law at the Civil Law Department, and the first of them was Maksymilian Szal, M.A., who gave a lecture entitled "Problems related to the admission to exchange trading of forward contracts for cryptocurrencies". In his speech, he also presented the security function of contracts, which can be used to "protect" commercial transactions, actually held - in investment portfolios - cryptocurrencies and types of investors for whom they may be an attractive financial instrument. Then a lecture was given by Dominik Leśniewski, M.A., who gave a speech on "Impact of cryptocurrency market development on the computer components market". At the beginning, the situation of the computer hardware market before the sudden increase in the value of cryptocurrencies and their interest in society was presented. Mr. Leśniewski also characterized the construction of cryptocurrency mining devices and explained why their development has such a large impact on the computer hardware market.

During the Conference, students from Białystok, Krakow, Lublin and Siedlce also took part. Above all, we enjoyed the presence of representatives from Belarus. One of the represented universities was the Yanka Kupala State University of Grodno. Alicja Gabis presented a lecture entitled "Гродненский государственный университет имени Янки Купалы (“Cryptocurrency and its legal protection in the Republic of Belarus"), in which she presented the latest legal regulations regarding cryptocurrencies in Belarus. The mentioned university was also represented by Vladimir Kovalchuk, who in his speech "Ripple as the most promising electronic payment system" focused on one cryptocurrency, showing its advantages in comparison to others. The situation of cryptocurrencies in Belarus was also presented by Polina 
Kowalczuk (“Криптовалюта в Республике Беларусь. / Cryptocurrency in the Republic of Belarus") and Wiktoria Biedrowicz ("Развитие криптовалюты в Республике Беларусь. / Development of cryptocurrencies in the Republic of Belarus."), both from the Polotsk State University. The presence of foreign students was very satisfactory, but Polish universities had a much larger number of representatives. Lublin and Maria Curie Skłodowska University were represented by Aleksandra Gwiazdowska and Natalia Grudniewska, with a lecture entitled "Where did the virtual money come from? The origin of cryptocurrencies." They familiarized the audience with the history of the first bitcoins, litecoins, dashcoins or monero. Next, Karolina Palka and Marek Stolorz from Jagiellonian University had a presentation entitled "ATMs and deposit machines servicing cryptocurrencies - legal problems." They discussed the principles of Bitcoinomats and then focused on the criminal aspect - specifically on the possibility of committing a crime using these devices.

The University of Natural Sciences and Humanities in Siedlce also had its representatives. Anna Zychowicz gave a lecture on the operation of bitcoin in Germany and the possibility to learn from these regulations in creating a Polish system for cryptocurrencies ("Private money - bitcoin status in Germany"). Also from this university was a lecture entitled "Bitcoin as an innovative currency" presented by Paulina Rowicka. The author presented the possibilities of technological development using bitcoins, but also the risks associated with the dissemination of this currency. Last speeches belonged to the hosts. Ewelina Marcińczyk presented the work "Making the virtual currency real. Cryptocurrencies in everyday use", which clearly showed that paying with this money is widely used. Łukasz Presnarowicz focused on a completely different aspect. In the study entitled "Other monetary intermediation, business activity on the cryptocurrency market" he presented virtual currencies from the point of view of laws, paragraphs and finances. Then Gabriela Raczykowska with a lecture entitled "The largest cryptocurrency mines in Europe. How does it work?" showed the technical side of the possibility of having its own virtual money by presenting places where such activity is run on a larger scale. Bartosz Borowik had a speech on "Bitcoin, as the currency of the black market. Influence of cryptocurrencies on crime.", in which examples were presented to show that bitcoin is already becoming a tool for committing crimes. The last speech was delivered by Sylwia Stupak and Katarzyna Mierzyńska, who presented the situation of virtual currencies in Poland, indicating deficiencies in the Polish system in this aspect ("Poland in the world of cryptocurrencies"). After thanking all invited guests and all participants, the Conference was closed at 6 p.m. by Magdalena Olchanowska, the president of the Student Financial Law Club.

The one-day Conference showed that the topic of virtual currencies is extremely broad. Presented papers brought the audience closer to the phenomenon of cryptocurrencies, which increasingly penetrate into everyday life. 